\title{
Living with HIV/AIDS: Stigma and Social Discrimination
}

\section{Hidup dengan HIV/AIDS: Stigma dan Diskriminasi Sosial}

\author{
Dewi Kurnia Putri ${ }^{1}$, Hema Malini ${ }^{1}$, Basmanelly ${ }^{2}$ \\ ${ }^{1}$ Magister of Nursing Science, Faculty of Nursing, Universitas Andalas, Limau Manis, \\ Pauh, Padang 25163, West Sumatra, Indonesia \\ ${ }^{2}$ Nurse Specialist, RSJ. Prof. HB. Saanin Padang, Jl. Raya Ulu Gadut Padang, Limau \\ Manis Selatan, Pauh 25129, West Sumatra, Indonesia \\ *Corresponding Author, e-mail: hemamalini@nrs.unand.ac.id
}

\begin{abstract}
The diagnose HIV/AIDS in Melayu community is often experience social discrimination and stigma. This situation could lead to mental health disorders among people with HIV/AIDS. This study explores the perceived stigma and social discrimination among people with HIV/AIDS, how they adapt with the situation. Using phenomenological approach, in-depth interview was conducted with seven participants, then analyzed using Collaizi approach. The result showed that most of the participants experienced stigma and lead to received social discrimination from community members such as neighbor, colleagues, relatives, close friend, and even the health professionals. Some of them can adapt well, however, most of them felt anger, depressed, and negative coping such as lying and anti-social. It is recommended to increase social awareness of this situation especially for providing support for people with HIV/AIDS, to improve their quality of life especially their mental health status.
\end{abstract}

Keywords: Mental Health, Social Supports, Stigma, Discrimination.

\begin{abstract}
Abstrak
Orang dengan HIV/AIDS (ODHA) pada masyarakat Melayu sering mengalami stigma dan diskriminasi sosial. Kondisi ini dapat mengakibatkan gangguan pada kesehatan mental. Penelitian ini berusaha mengeksplorasi stigma dan diskriminasi sosial yang diantara ODHA, dan bagaimana mereka beradaptasi. Pendekatan fenomenologi dengan melakukan interview pada tujuh partisipan, data kemudian dianalisa dengan pendekatan Collaizi. Hasil penelitian menunjukkan adanya diskriminasi dari tetangga, teman, keluarga, dan tenaga kesehatan. Para ODHA sebagian bisa beradaptasi, sebagian lagi merasa marah, berbohong dengan kondisi dan anti-sosial. Diharapkan masyarakat dapat meningkatkan kesadaran sosial terutama dalam memberikan dukungan pada ODHA, agar kualitas hidup mereka dapat ditingkatkan terutama pada status kesehatan mental.
\end{abstract}

Kata Kunci: Kesehatan Mental, Dukungan Sosial, Stigma, Diskriminasi.

Copyright (C) 2019 Universitas Semarang. All rights reserved.

\section{Introduction}

In recent years, the number of people living with HIV/AIDS (PLWHA) increase drastically. The HIV/AIDS cases can be found across all the province in Indonesia. Riau, as one of the provinces in Indonesia, have HIV/AIDS cases is quite high, with the $9^{\text {th }}$ to $11^{\text {th }}$ for the incidence of HIV and the $13^{\text {th }}$ rank for the for the incidence of AIDS in Indonesia (Ditjen PP \& PL Kementerian Kesehatan RI, 2014).

According to data of the National Commission for AIDS (KPA), in Riau Province, it showed 1,889 cases of HIV and AIDS cases 1,525 in 2015. The city of Pekanbaru, as

Article History: Received April 06, 2018; Revised January 10, 2019; Accepted January 24, 2019; Published January 31, 2019 
the capital city of Riau, the number of people with HIV/AIDS in a population is around 806 cases. The city of Pekanbaru is a town that has a diversity in the community members that are still largely by Malay ethnic. The high cases of HIV/AIDS epidemic are suspected because Pekanbaru is a transit city, a trading city and supported by an adequate transport facilities' as well as the level of mobility that relatively high. The increasing development characterized by rapid development of shopping centers and entertainment venues. Such condition that causes society of Pekanbaru is very vulnerable to sexual transmitted diseases such as HIV and AIDS (Dinas Kesehatan Provinsi Riau, 2015).

For PLWHA, it has impact not only having consequences to changes in physiological health, will also have a psychological impact. The community still considered HIV/AIDS is a disgrace disease due to sin or misbehavior. Thus, the stigma towards patients cause psychological pressure mainly on the sufferers, their family and closed relatives.

Some of psychosocial condition would dramatically changes when an individual declared or known for suffering from HIV/AIDS. Most of psychosocial changes that could be identified such as living in stress, depression, antisocial and behavioral changes. The reality of rejection towards people with HIV/AIDS will potentially led to the progressivity of infection of HIV, since people with this disease would hide their diagnosis and their conditions (Nasronudin, 2007). A study conducted by Hasanah, Sarikusuma, \& Herani (2012) found that PLWHA by the social environment that their condition as result of karma or punishment from the creator.

In addition to the presumptive negative, PLWHA suffer from various forms of discrimination such as separation of utilities among family member, excluded from the community and work environment. The consequences of negative labelling and discriminated, the psychological impact will be experienced by the PLWHA (Hasanah et al., 2012).

Psychosocial burden also occurs in people with HIV/AIDS. Most of PLWHA get negative labeling and discrimination from their neighborhood. The negative treatment that they received such as: abandoned by their couples, isolated from the families, lost their rights in the family and excluded from the social environment. It is the psychological effect on these people will lead them to the sadness, angry and even depressed. At the end, these people will become antisocial and will lead to mental health disorders due to lack of social interaction. Despite, the presence of stigma and discrimination among people with HIV/AIDS, some of them able to survive and adapt.

As the Roy's adaptation theories stated, some people who were exposed to certain stimulus in their social environment, will generate an adaptive response and the occurrence of adaptation process would be supported by some others. An adaptive response can increase the integrity of that lead to health so that the individual can afford to survive, grow and develop as well as interact with environment. Meanwhile, the effective response will have an impact on individual failure in adapting to the environment (Alligood, 2014). A study in the United States found that there are several factors that influenced the stigma: lack of knowledge of the HIV and AIDS; misperception of the infection process of HIV; and misconduct in treatment and management of the disease (Sofro, 2015).

Living with the stigma and social discrimination has exposed PLWHA to a certain situation that they are not only need to cope with their health status, but also, they need to develop a coping mechanism to overcome the psychosocial pressure. If the situation 
that experienced by the PLWHA has no support or solution will lead to other problems not only mental health disorders but also the social problems. A proposed solution is needed to overcome the situation. Thus, to identify the problems from PLWHA perspective, a qualitative study needs to be conducted. This study aims to explore the lived experiences of people with HIV/AIDS with perceived stigma and social discrimination and the coping and adaptation process in overcoming the stigma.

\section{Methodology}

This study is a qualitative research design to explore the lived experience of PLWHA. Using phenomenology design, this study aims to investigate the participants' perceptions of perceived stigma and social discrimination and how their reaction to this condition and how they cope with the situation (Biddix, 2016). Phenomenological research is an inductive and descriptive method used to investigate and describe phenomena as they appear in their full depth and breadth (Cho \& Trent, 2006).

Criterion-based sampling was used to select the participants for this study, such as that the people with HIV/AIDS had experienced the phenomena under investigation and that they were able to adequately articulate their experience to the researchers (Streubert $\&$ Carpenter, 2011). The participants were sourced from the non-government organization in Pekanbaru city. Suitable participants with inclusion criteria such as reported experienced some social discrimination and stigma and willing to involve in this study were contacted by the NGO officer and referred to the researchers who subsequently contacted the identified participants. A total of seven participants agreed to participate in the study.

The participants were contacted and suitable venues for individual interviews were determined. The researchers used an existential phenomenological interview style with the focus on open-ended comments and discussion. The interviews, which concentrated on the experiences of types of stigma and social discriminations, their coping in adapting in order to obtain a comprehensive description of the participants' experiences. Openended questions were used to focus on specific themes that arose during the interview procedure. Researchers also obtained field notes and interview with the NGO representatives to validate the information or to have further information towards the research topics.

In order to obtain a comprehensive idea of the participants' experiences, the researchers using the Collaizi methods which first will transcript the interview and after that, the researcher will read, re-read and listen overtimes to emerge with the interview situation. The researcher also 'bracketed' existing theories, knowledge and experiences concerning the phenomenon under investigation (Creswell, 2006). This enabled the researchers to encounter the phenomenon in an open environment and thus learn from the participants' experiences. Bracketing is an essential process in phenomenological research (J W Creswell, Hanson, Clark Plano, \& Morales, 2007). The next process, the researcher classifies all the keywords and meaning units into groups and find the categories then developed sub-themes and themes (Streubert \& Carpenter, 2011).

\section{Results and Discussion}

There were seven participants in this study consist of four men and three women within the age between 24 to 38 years old. Most of the participants have education level of high school to bachelor, from housewives until business man, and all of them are Malay ethnics. The length of have been diagnosed with HIV/AIDS was between two until 15 
years, and most of them living with their families.

It is identified the risk factors of the participant experienced HIV/AIDS is due to the various numbers of sexual partners and using the needle injected drugs-shared groups. Several themes emerged in the interviews. These themes were labelled as the perceived and the sources of stigma and social discriminations; psychological response and coping mechanisms towards the stigma and social discriminations; and social supports in adapting the stigma.

Some issues on how therapeutic communication could be enhance as the mandatory skills that most of health workers need to perform. People living with HIV/AIDS need some personal approach through a good therapeutic communication. The use of social media especially in improving the awareness and knowledge of community especially the young age, would benefits many community members.

Perceived and Sources of Stigma and Social Discriminations

Stigma is a negative judgment against a person or group of people in the community. The stigma is categorized into two, namely internal and external stigma. Internal stigma is the stigma that comes from within yourself, describe how someone's feelings about how others see themselves which can lead to depression and resignation that makes people become introvert. Discrimination is a form of external stigma from the environment and community, where this could lead the PLWHA hide the disease and could prevent the appropriate and necessary intervention for HIV/AIDS.

Sofro (2015) stated some other situation that associated stigma and discrimination. Stigma is a dynamic process of devaluation of contamination or loss if someone's' belief in the eyes of other. Meanwhile, discrimination is a real threat against a person who has given a stigma. Discrimination against people living with HIV/AIDS to occur at various level, ranging from the family, the community surrounding, and the institution up to the national level. Based on the research result, the form of discrimination and stigma experienced by PLWHA is derived from the society, family and health services.

The stigma and discrimination experienced by PLWHA comes from close friends, neighbors, and the colleague in workplace. Whereas, in the family, the stigma and discrimination of these people come from their in-laws, siblings, and other family members. Form of discrimination experienced by PLWHA such as existence of the separation of shower, food utilities, avoid shaking or touching the PLWHA and isolated them from the family occasion of gathering

Like some of these expressions:

"One of my neighbor whose kids used to my close friends asked his kids to unfriend me and stay away from me because my conditions could easily be infected them."

"In my workplace, I has responsibility providing the drinks and snacks for the employee, I was fired when the employer knew that I have HIV/AIDS. My boss said I will infect all the others workers."

"My brother in-law, since I lived with my sisters, told her to differentiate all the utilities I used in the house for example the plates, spoon and glasses. He said I have a very dangerous disease, I can contaminate his family. Even he planned to ask me live somewhere else other than his home."

While stigma and discrimination health services obtained from health workers such as nurses and physician during the PLWHA attended the health facilities. Even, for the health services they received is different from other patients. The PLWHA could feel the negative feeling towards their existence in the health facilities. Thus, it is a need for health professionals to improve their skill especially in therapeutic communication, as the 
therapeutic communication could have impact on the social perception towards the image of health care or hospitals (Riauan \& Shasrini, 2017).

For example: of discrimination in separation using the examination room, onsite health services provided do not comply with the standard services are obtained, and some of the health workers deny or reject to provide health care services.

"One day I came to health centre, I want to consult to the doctor ... but the receptionist there told me that I need to go, they do not serve patients with my condition (HIV)."

"I was asked to wait for a long time in one of policlinic in a hospital. When it came to my turn, the doctor told me, he cannot service me because I have HIV and they don't have the facility for me."

"I was waiting for my wives who in laboring, I wait in the patients' ward. All the other family were given proper plate for their lunch, but for me they provide me with plastic plate."

Psychological Response and Coping Mechanisms

This study identifies the psychological response of people with HIV/AIDS when they received stigma and social discriminations. Most of them were angry, disappointed; and despair. When the participants angry with the situation they experienced, they would encounter the person directly and threaten them.

"I came to my brother in-law, and I said to him, if you did not anything about my disease, you should not pretend that you know. You are just an idiot."

"I will report you to the police because you have been unfair to me and conduct unpleasant thing."

Some of the participants would be angry and blame themselves because their misbehavior in the past that cause them to have the disease. All these responses, that most of the participants are still have maladaptive responses. On the other hand, some of the participants stated that they felt disappointed with the situation and tried to explain logical information about their diseases to other.

"I did not like for threated unfair, but sometimes, it is because they did not know anything about the disease, they need to find the right information."

However, some of the participants felt despair to know the reality that even the health professionals can have stigma and did some discrimination to them.

"I can't believe, he is a doctor, he knows about my disease, how could he treat me like that."

"Even the hospitals staff know about my disease and its situation, how could they treat me and my family worse."

Social Supports in Adapting the Stigma

With the stigma and discrimination that the participants received, social supports from family and peer also received by them. The peer support especially from the NGO staff member and also all other PLWHA has positive response. The NGO regularly provided and distributed flyer to the community to inform about HIV/AIDS. The peer continuously motivated them to maintain they health status by consuming the ARV regularly.

It is stated that peer support group has significant role in enhancing the meaning and quality life of people with HIV/AIDS. The supports from friends make them confidence and motivated in regularly taking ARV. Positive supports from the surrounding environment have significant impact on the quality of life for HIV/AIDS patients (Diatmi \& Fridari, 2014). 
The results of the qualitative research illustrated that support groups can reduce the level of depression, reduce complaints, and better adaptation towards psychology and physical problems (O'brien, Davis, Strike, Young, \& Bayoumi, 2009). The stigma and discrimination the PLWHA received during attending the health care services, it will also affect their coping mechanisms. In this study, it was found that some of the PLWHA are covering or avoid being honest about their medical condition when they visited the health services for other health problems. They conducted this due to the fear of being reject or don not receive the appropriate health care services. This situation is obviously having high risk against the spread of HIV/AIDS, where the general precaution would not be applied by health workers during the services.

The need for a better understanding on the health professional in providing the health services in particular PLWHA, because these persons do not only need some physical or biological treatment, but also, they need to have social and physiological support in order to maintain and improve their quality of life. Consultant Liaison Psychiatry (CLP) is a branch of medical science of the psychiatry which provides the service of psychiatry on patients with common medical conditions that experiencing mental health problems due to their medical conditions (De Giorgio et al., 2015).

In the future, this CLP could be considered as one of the services from mental health nurses or doctors. The formation of the CLP can grow medical personnel, the medical and related ranks especially on health care in the general hospital for people with HIV/AIDS in delivering health care services in a comprehensive manner, so as to lower the incidence of stigma and discrimination particularly on the health services. The formation of the communication between cross sector can improve the effectiveness of the consultation process as well as ensure the intervention accurate, timely and provide possibility of better health services.

Some of the factors that cause the appearance of stigma and discrimination is the lack of knowledge about HHIV/AIDS, the wrong perception about how the HIV/AIDS transmitted, and the existence of prejudice and fear to excessive social sensitive problems (Sofro, 2015). In a study by Rokhmah (2014) about the relationship of knowledge of HIV/AIDS towards stigma to PLWHA among high school students in Surakarta revealed there was a misunderstanding of HIV transmission among students and teachers as well. From the study, it also showed that students who have the good level of knowledge about HIV/AIDS would have more low risk of having stigma than with a student with a high knowledge related HIV/AIDS. Using the social media, in educating teenagers about HIV/AIDS to increase awareness and reduce stigma is effective. A study conducted by Aprinta E.B \& Dwi S.W (2017) suggested that even teenagers spent most of their time to use social media, it did not decrease their awareness to the social condition, since some of them are still involve and willing to look for more information of social or community surrounding.

\section{Conclusion}

People with HIV/AIDS experienced stigma and social discrimination from their family, friends, workplace and even health staff member. Some of them can cope well, however many of them felt angry, disappointed, and despairs. This condition could affect the quality of life of people with HIV/AIDS. Continuum support from peer group, family member, health professionals even the community is needed. There is also an urgent need to increase the awareness of community member about HIV/AIDS. Flyer, pamphlets, seminars are some of the way to socialize and spread the information about the disease. 
This is needed in order to reduce the stigma and social discrimination among people with HIV/AIDS in order to increase their health status and reduce the mental health disorders among them. Increasing the skill of health professionals in performing therapeutic communication and using the social media to delivering health information regarding HIV/AIDS would gain many benefits not only for the health professionals, community but also for the PLWHA themselves.

\section{Acknowledgements}

We would like to say thank you to all participants and social workers that involved and facilitated this study.

\section{References}

Alligood, M. (2014). Nursing Theorists and Their Work. St. Louis, Missouri: Mosby, Elsevier.

Aprinta E.B, G., \& Dwi S.W, E. (2017). Correlation of Social Media Uses and Social Consciousness Level in Teenagers. Jurnal The Messenger, 9(1), 65-69.

Biddix, J. P. (2016). Research Rundowns: Qualitative research design, 1-3. Retrieved from https://researchrundowns.files.wordpress.com/2009/07/rrqualdesign_72009.pdf\% 5Cnhttps://researchrundowns.com/qual/qualitative-research-design/

Cho, J., \& Trent, A. (2006). Validity in qualitative research revisited. Qualitative Research, 6(3), 319-340. https://doi.org/10.1177/1468794106065006

Creswell, J. W. (2006). Five Qualitative Approches to Inquiry.

Creswell, J. W., Hanson, W. E., Clark Plano, V. L., \& Morales, A. (2007). Qualitative research designs. The Counseling Psychologist, 35(2), 236-264. https://doi.org/http://dx.do.org/10.4135/9781849208826.n4i

De Giorgio, G., Quartesan, R., Sciarma, T., Giulietti, M., Piazzoli, A., Scarponi, L., ... Piselli, M. (2015). Consultation-Liaison Psychiatry - From theory to clinical practice: An observational study in a general hospital. BMC Research Notes, 8(1), 4-9. https://doi.org/10.1186/s13104-015-1375-6

Diatmi, K., \& Fridari, I. G. . D. (2014). Hubungan Antara Dukungan Sosial dengan Kualitas Hidup pada Orang Dengan HIV dan AIDS (ODHA) di Yayasan Spirit Paramacitta. Jurnal Psikologi Udayana, 1(2), 353-362.

Dinas Kesehatan Provinsi Riau. (2015). Profil Kesehatan 2015. Pekan Baru.

Ditjen PP \& PL Kementerian Kesehatan RI. (2014). Statistik Kasus HIV/AIDS di Indonesia. Jakarta.

Hasanah, N., Sarikusuma, H., \& Herani, I. (2012). Konsep Diri Orang dengan HIV/AIDS (ODHA) yang Menerima Label Negative dan Diskriminasi dari Lingkungan Sosial. Psikologi-Online, 1, 29-40.

Nasronudin. (2007). HIV/AIDS Pendekatan Biologi Molekuler, Klinis dan Sosial. Surabaya: Airlangga University Press.

O’brien, K. K., Davis, A. M., Strike, C., Young, N. L., \& Bayoumi, A. M. (2009). Putting episodic disability into context: A qualitative study exploring factors that influence disability experienced by adults living with HIV/AIDS. Journal of the International AIDS Society, 12(1), 1-11. https://doi.org/10.1186/1758-2652-12-30

Riauan, M. A. R. I., \& Shasrini, T. (2017). Therapeutic Communications Impact On The Image Of Health Care (Study At Regional Public Hospital Of Arifin Achmad Pekanbaru). Jurnal The Messenger, 9(1), 31-43. 
Rokhmah, D. (2014). Implikasi Mobilitas Penduduk dan Gaya Hidup Seksual Terhadap Penyebaran HIV/AIDS. Jurnal Kesehatan Masyarakat, 9(2), 183-190.

Sofro. (2015). Sehat dan Sukses dengan HIV/AIDS. Jakarta: PT Gramedia.

Streubert, H. J., \& Carpenter, D. R. (2011). Qualitative Research in Nursing Advancing the Human Imperative (5th Edition). China: Lippincott Williams \& Wilkins. 